\title{
Helminth parasites of cats from the Vientiane Province, laos, AS INDICATORS OF THE OCCURRENCE OF CAUSATIVE AGENTS OF HUMAN PARASITOSES
}

\author{
SCHOLZ T.*, UHLÍrovÁ M.* \& DITRICH O.*
}

\section{Summary:}

A total of 55 domestic cats (Felis catus f. domestica) and one wild (Bengal) cat (Prionailurus bengalensis) from the Vientiane Province, central Laos, were examined for helminth parasites with emphasis given to potential human parasites. The following species were found (parasites infective to man marked with an asterisk): Opisthorchis viverrini*, Haplorchis pumilio*, H. taichui*, H. yokogawai ${ }^{\star}$, Stellantchasmus falcatus* (Digenea); Spirometra sp. *, Dipylidium caninum*, Taenia taeniaeformis (Cestoda); Capillariidae gen. sp., Toxocara canis*, T. cati*, Ancylostoma ceylanicum*, A. tubaeforme, Gnathostoma spinigerum* Physaloptera preputialis (Nematoda); and Oncicola sp. (Acanthocephala). This study demonstrated that examination of cats may provide useful data on the occurrence of helminths which are potential causative agents of human diseases.

KEY WORDS : helminths, cats, Laos, human parasites, prevalence, epidemiology.
Résumé : LES HELMINTHES PARASITES DU CHAT DE LA PROVINCE DE VIENTIANE, LAOS, INDICATEURS DE LA PRÉVALENCE DES PARISITOSES HUMAINES

Un total de 55 chats domestiques (Felis catus $f$. domestica) et un chat sauvage (Bengall (Prionailurus bengalensis) de la province de Vientiane, au centre du Laos, ont été examinés à la recherche $d$ 'helminthes parasites en mettant l'accent sur ceux qui peuvent être transmis à l'hommes. Les espèces suivantes ont été retrouvées lles parasites infestants pour l'homme sont suivis d'un astérisque): Opisthorchis viverrini *, Haplorchis pumilio*, H. taichui *, H. yokogawai *, Stellantchasmus falcatus * (Digenea); Spirometra sp. *, Dipylidium caninum *, Taenia taeniaeformis (Cestoda); Capillariidae gen. sp., Toxocara canis *, T. cati *, Ancylostoma ceylanicum *, A. tubaeforme, Gnathostoma spinigerum *, Physaloptera preputialis (Nematoda); and Oncicola sp. (Acanthocephala). Cette étude démontre que l'examen de chats peut apporter des informations utiles sur la prévalence des helminthiases potentiellement transmissibles à l'homme.

MOTS CLÉS : helminthe, chat, Laos, parasitose humaine, prévalence, épidémiologie.

sites due to the morphological similarity of their eggs (Ditrich et al., 1992).

Many helminths infecting man also occur in other mammals, including domestic cats, which live close to humans and consume similar food. Cats may thus serve as source of infection for some human parasites and indicate their occurrence in a specific locality (Chandler, 1925; Muller, 2002). Adult worms recovered from these hosts can give an indication of the infection in humans because the larvae and eggs of many parasites of man are indistinguishable (Muller, 2002).

Data on the occurrence of the helminth parasites of cats in Southeast Asia are rather scarce (e.g., Hinz, 1980; Shaikh et al., 1982; Khan, 1987; Rajavelu \& Raja, 1988) and almost no information exists from countries of the past Indochina, including Laos (Segal et al., 1968). Ditrich et al. (1990) and Giboda et al. (1991a, b) listed five species of trematodes and other endohelminths, most not identified to the species or even the genus level, from cats in central Laos. Scholz \& Ditrich (1990) and Scholz et al. (1991a, 1992) described the morphology of the surface of the nematode Gnathostoma spinigerum, the liver fluke Opisthorchis viver-
* Institute of Parasitology, Academy of Sciences of the Czech Republic \& Faculty of Biological Sciences, University of South Bohemia, České Budějovice, Czech Republic.

Correspondence: T. Scholz, Institute of Parasitology, Academy of Sciences of the Czech Republic, Branišovská 31, 37005 České Budějovice, Czech Republic.

Tel.: ++420-38-777-5431 - Fax: ++420-38-5310-388.

E-mail: tscholz@paru.cas.cz 
rini and heterophyid trematodes of the genera Haplorchis and Stellantchasmus. However, detailed data on the species composition of the helminths occurring in cats in this country and rates of infection with these parasites have not been provided.

In this study, a survey of endoparasitic helminths found in cats from three regions of central Laos is presented and the suitability of these hosts as possible indicators of the occurrence of potential human parasites is discussed.

\section{MATERIAL AND METHODS}

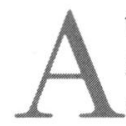
total of 55 domestic cats (Felis catus $\mathrm{f}$. domestica Linnaeus, 1758) and one Bengal cat (Prio_ nailurus bengalensis Kerr, 1792) were examined from the following areas of the Vientiane Province, central Laos, between May and September 1989:

i) Vientiane (markets, temples and streets of the Lao capital; $18^{\circ} 45^{\prime} \mathrm{N}$; $\left.102^{\circ} 38^{\prime} \mathrm{E}\right)-27$ domestic cats examined;

ii) Ban Thinkeo, Keo-Oudom District ( $18^{\circ} 33^{\prime} \mathrm{N} ; 102^{\circ}$ 32' E) - six domestic cats;

iii) villages around Nam Ngum water reservoir (18 $25^{\prime}$ $18^{\circ} 45^{\prime} \mathrm{N}$; $102^{\circ} 30^{\prime}-102^{\circ} 45^{\prime} \mathrm{E}$; see Ditrich et al., 1990 for a survey of localities and cats examined) -22 domestic cats. The Bengal cat, which was shot in the mountains around the reservoir, was purchased in the market of the village of Hanunghok.

The cats were anaesthetized and then killed by overdoses of ether and examined in the laboratory using standard procedures. Trematodes, cestodes and acanthocephalans were fixed with $4 \%$ formaldehyde solution under coverslip or slide pressure, stained with Mayer's carmine, dehydrated in graded ethyl alcohol, and mounted in Canada balsam. Nematodes were fixed with hot $4 \%$ formaldehyde solution. Small nematodes (Ancylostoma) were cleared in graded glycerine solution (1:20-1:2) while large nematodes (ascarids, spirurids) were measured under a dissecting microscope and selected specimens were dissected to observe the structure of the oesophagus.

For scanning electron microscopy (SEM), standard procedure were used. Samples were examined using a Jeol JSEM 6300 microscope and all specimens studied have been deposited in the helminthological collection of the Institute of Parasitology, AS CR, České Budějovice (see Table I for collection numbers).

\section{RESULTS}

A total of 16 species of the following helminth parasites were found in domestic cats from the Vientiane Province, central Laos (Table I): five species of trematodes (Digenea), namely Opisthorchis viverrini (Poirier, 1886) (Opisthorchiidae), Haplorchis pumilio (Looss, 1896), H. taichui (Nishigori, 1924), H. yokogawai (Katsuta, 1932), Stellantchasmus falcatus (Onji \& Nishio, 1916) (all Heterophyidae), three tapeworms (Cestoda), i.e. Spirometra sp. (Diphyllobothriidae), Dipylidium caninum (Linnaeus, 1758) (Dipylidiidae), Taenia taeniaeformis (Batsch, 1796) (Taeniidae) (Figs 1-2); seven nematodes (Nematoda), i.e. Capillariidae gen. sp.; Toxo-

\begin{tabular}{|c|c|c|c|c|c|c|c|c|c|}
\hline \multirow[b]{2}{*}{ Species } & \multirow[b]{2}{*}{$\begin{array}{c}\text { Collection } \\
\text { number }\end{array}$} & \multicolumn{2}{|c|}{$\begin{array}{l}\text { Vientiane } \\
(\mathrm{n}=27)\end{array}$} & \multicolumn{2}{|c|}{$\begin{array}{c}\text { Ban Thinkeo } \\
(n=6)\end{array}$} & \multicolumn{2}{|c|}{$\begin{array}{c}\text { Nam Ngum } \\
\text { water reservoir } \\
(n=22)\end{array}$} & \multicolumn{2}{|c|}{$\begin{array}{c}\text { Total } \\
(\mathrm{n}=55)\end{array}$} \\
\hline & & $\begin{array}{c}\text { Prevalence } \\
(\%)\end{array}$ & $\begin{array}{c}\text { Mean } \\
\text { intensity } \\
\text { (min.-max.) }\end{array}$ & $\begin{array}{c}\text { Prevalence } \\
(\%)\end{array}$ & $\begin{array}{c}\text { Mean } \\
\text { intensity } \\
\text { (min.-max.) }\end{array}$ & $\begin{array}{c}\text { Prevalence } \\
(\%)\end{array}$ & $\begin{array}{c}\text { Mean } \\
\text { intensity } \\
(\min .-\max .)\end{array}$ & $\begin{array}{c}\text { Prevalence } \\
\text { (\%) }\end{array}$ & $\begin{array}{c}\text { Mean } \\
\text { intensity } \\
\text { (min.-max.) }\end{array}$ \\
\hline Haplorchis pumilio & D-256 & - & - & - & - & 24 & $3(1-6)$ & 11 & $3(1-6)$ \\
\hline Haplorchis taichui & D-260 & - & - & - & - & 52 & $26(1-130)$ & 22 & $26(1-130)$ \\
\hline Haplorchis yokogawai & D-257 & - & - & - & - & 52 & $25(1-88)$ & 20 & $25(1-88)$ \\
\hline Opisthorchis viverrini & D-254 & 15 & $147(4-450)$ & 17 & 1 & 27 & $20(1-74)$ & 20 & $64(1-450)$ \\
\hline Stellantchasmus falcatus & D-255 & - & - & - & - & 4 & $14(3-24)$ & 1 & $14(3-24)$ \\
\hline Dipylidium caninum & $\mathrm{C}-237$ & 30 & $11(1-30)$ & - & - & 23 & $13(1-54)$ & 24 & $12(1-54)$ \\
\hline Spirometra sp. & C- 242 & 22 & $1(1-2)$ & - & - & 5 & 2 & 13 & $1(1-2)$ \\
\hline Taenia taeniaeformis & C-239 & 26 & $1(1-4)$ & 17 & 1 & 9 & 1 & 18 & $1(1-4)$ \\
\hline Ancylostoma ceylanicum & $\mathrm{N}-802$ & 70 & $32(1-222)$ & 67 & $19(6-30)$ & 68 & $6(1-18)$ & 69 & $20(1-222)$ \\
\hline Ancylostoma tubaeforme & N-803 & - & - & 17 & 2 & - & - & 2 & 2 \\
\hline Gnathostoma spinigerum & N-489 & 4 & 1 & - & - & - & - & 2 & 1 \\
\hline Physaloptera praeputialis & $\mathrm{N}-339$ & 41 & $8(1-34)$ & 50 & $7(2-8)$ & 4 & 7 & 27 & $7(1-34)$ \\
\hline Toxocara canis & $\mathrm{N}-443$ & 11 & $11(1-23)$ & - & - & - & - & 5 & $11(1-23)$ \\
\hline Toxocara cati & N-801 & 6 & $6(1-18)$ & 33 & $8(5-10)$ & 9 & $4(1-6)$ & 11 & $6(1-18)$ \\
\hline
\end{tabular}

Table I. - Helminths found in domestic cats in Vientiane Province, central Laos. 


\begin{tabular}{lcc}
\hline \multicolumn{1}{c}{ Character } & $\begin{array}{c}\text { Male } \\
(\mathrm{n}=33)\end{array}$ & $\begin{array}{c}\text { Female } \\
(\mathrm{n}=36)\end{array}$ \\
\hline Length of body $(\mathrm{mm})$ & $3.4-7.8$ & $4.3-10.7$ \\
Width of body & $140-290$ & $150-360$ \\
Buccal capsule & $59-170$ & $63-221$ \\
$\quad$ (length $\times$ width) & $53-145$ & $53-184$ \\
Oesophagus & $370-870$ & $510-980$ \\
$\quad$ length $\times$ width) & $90-170$ & $80-190$ \\
Distance of nerve ring & $281-442$ & $315-548$ \\
Distance of excretory pore & $221-620$ & $340-720$ \\
Copulatory bursa & $210-430$ & - \\
$\quad$ (length $\times$ width) & $220-470$ & - \\
Length of spicules & $620-890$ & - \\
Distance of vulva from posterior end (mm) & - & $1.6-4.0$ \\
Size of eggs & & \\
$\quad$ length & - & $43-59$ \\
$\quad$ width & - & $27-39$ \\
\hline
\end{tabular}

Table II. - Measurements (in micrometres unless otherwise stated) of Ancylostoma ceylanicum (Looss, 1911).

cara canis (Werner, 1782) (Fig. 8), T. cati (Schrank, 1788) (Figs 9-10) (Toxocaridae), Ancylostoma ceylanicum (Looss, 1911) (Fig. 11; Table II), A. tubaeforme (Zeder, 1800) (Fig. 12) (Ancylostomatidae), Gnathostoma spinigerum (Owen, 1836) (Gnathostomatidae), Physaloptera praeputialis (von Linstow, 1889) (Figs 37) (Physalopteridae); and one thorny-headed worm (Acanthocephala), namely Oncicola sp. (Figs 13-14) (Oligacanthorhynchidae).

Table I presents the prevalence and intensity of infection with individual parasite species in cats from three different regions in central Laos. All but two cats harboured at least one helminth species, with one host having been infected with as many as six helminth species; $7 \%$ of the cats harboured five species, $16 \%$ four species, $20 \%$ three species, $22 \%$ two species, and $29 \%$ one helminth species.

The Bengal cat harboured the following helminths: the cestode Taenia taeniaeformis (20 specimens), nematodes Ancylostoma ceylanicum (23), Capillariidae gen. sp. (one female), Physaloptera praeputialis (57), and the acanthocephalan Oncicola sp. (164).

\section{DISCUSSION}

I cats from the Vientiane Province, Central Laos, as many as 16 species of helminth parasites were found. Parasitic nematodes were the dominant helminth group as to the species richness and prevalence, but small intestinal flukes of the genus Haplorchis were the most abundant parasites, with the intensity of infection reaching up to several hundreds of specimens (Table I).

The species spectrum of the helminth parasites found in Laos does not differ significantly from that reported from the same hosts in other countries in Southeast Asia but differences exist in infection rates of the individual parasite species (Shaikh et al., 1982; Fujinami et al., 1983; Fukase et al., 1984; Asato et al., 1986; Khan, 1987; Rajavelu \& Raja, 1988; Saito et al., 1998).

Most of the helminths found in cats in Laos are potential human parasites, or have been reported from accidental infections in man. The highest number of the species are the causative agents of fish-borne helminthoses, namely the flukes Opisthorchis viverrini, Haplorchis species, Stellantchasmus falcatus, and the spiruroid nematode Gnathostoma spinigerum.

In Southeast Asia, the liver fluke O. viverrini causes opisthorchosis which affects millions of persons (Harinasuta \& Vajrasthira, 1960; Wykoff et al., 1965; Rim et al., 1994; Muller, 2002).

All trematodes of the family Heterophyidae found in this study belong to the so called "small intestinal flukes", which cause heterophyidosis, with most cases occuring in Southeast Asia (Velasquez, 1982; Radomyos et al., 1983, 1990; Sohn et al., 1989; Chai \& Lee, 1990; Muller, 2002). Adult trematodes infecting fish-eating birds and mammals differ from each other by the morphology and armament of the ventrogenital complex (Pearson, 1964).

Prosobranchiate snails serve as the first and freshwater fish, in particular cyprinids, and as the second intermediate hosts of both $O$. viverrini and the heterophyids (Pearson, 1964; Wykoff et al., 1965; Scholz et al., 1991b; Abd El-Kader Saad \& Abed, 1995).

Definitive hosts of the spiruroid nematode G. spinigerum are felids and canids, but man can also become infected after consuming second intermediate or paratenic hosts, in particular freshwater fish (Miyazaki, 1960; Daengsvang, 1982; Anderson, 2000).

Frogs and reptiles are potential sources of human infections with species of the pseudophyllidean cestode genus Spirometra. Plerocercoids of this cestode can migrate within the human body, causing sparganosis, the highest prevalence of which is in East and Southeast Asia (Ausayakhun et al., 1993; Chang et al., 1999; Veena Tandon \& Imkongwapang, 1999; Muller, 2002)

Cats in Laos were also infected with Ancylostoma spp. as well as Toxocara canis and T. cat $i$ that cause the syndrom larva migrans (Davies et al., 1993; Muller, 2002).

Migration of infective larvae of species of Toxocara within internal organs or in the eyes (ocular larva migrans) in an inappropriate host may result in serious health complications (Glickman, 1993; Magnaval et al., 2001; Taylor, 2001)

The hookworm A. ceylanicum has been reported from man in India, Thailand, the Philippines, Taiwan, and Japan (Velasquez \& Cabrera, 1968; Yoshida et al., 

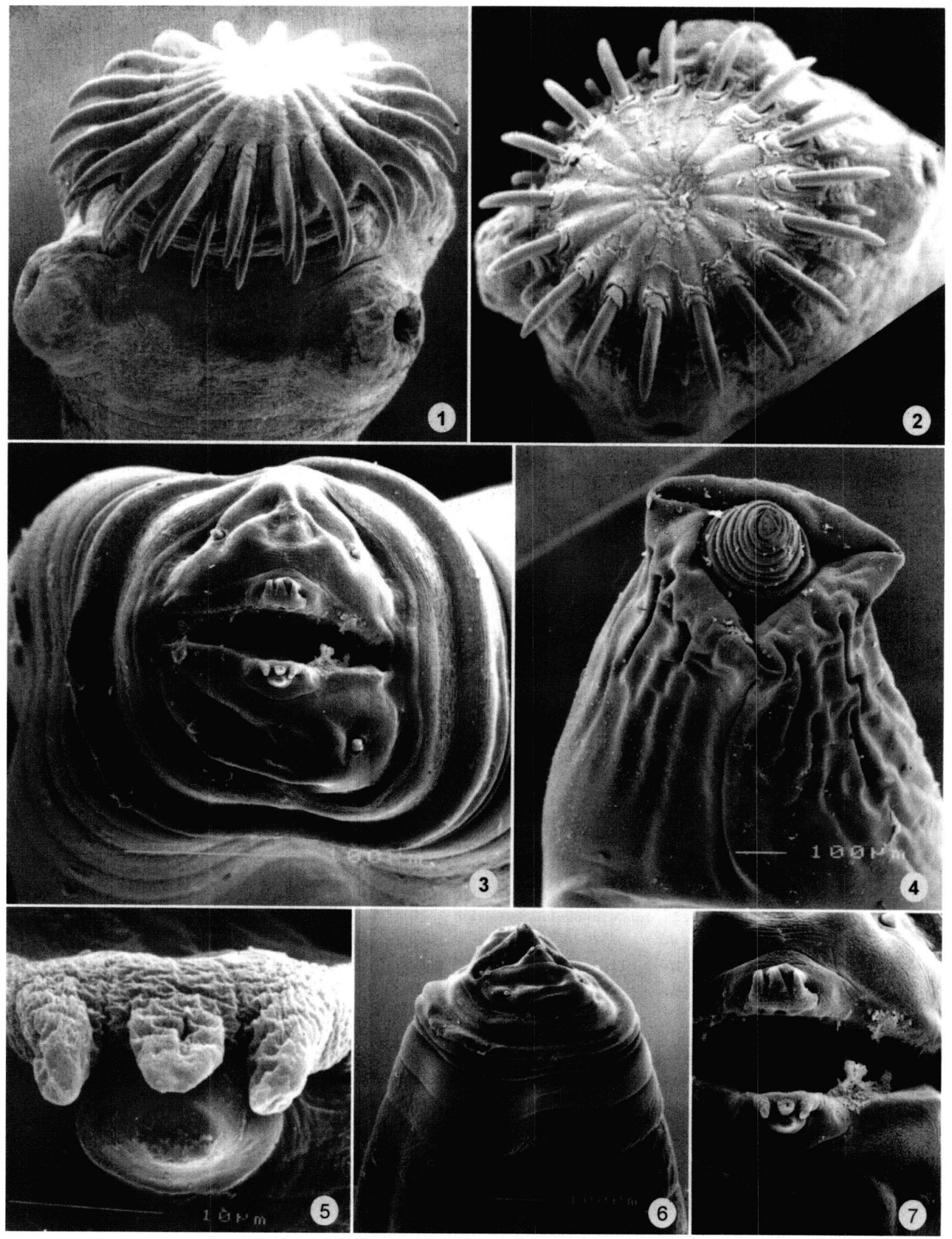

Figs 1-2. - Taenia taeniaeformis. 1. Scolex; subapical view. 2. Rostellum with hooks; apical view. Figs 3-7. - Physaloptera praeputialis. 3. Anterior end; apical view. 4. Posterior end of female; subapical view. 5. Detail of circumoral lips; apical view. 6. Anterior end; subventral view. 7. Mouth region; apical view (SEM photomicrographs). 

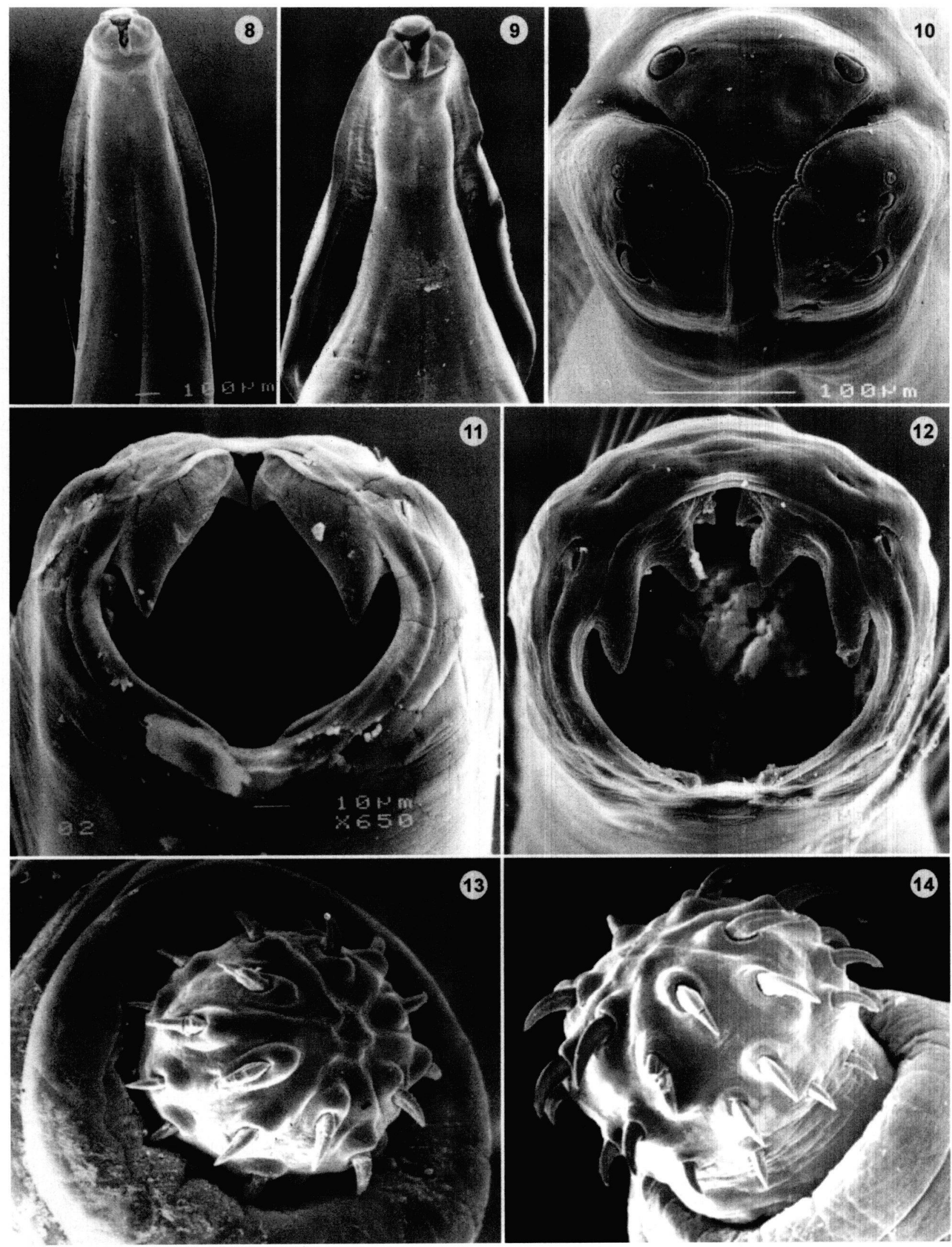

Fig. 8. - Toxocara canis. Anterior end with cervical alae; ventral view. Figs 9-10. - Toxocara cati. 9. Anterior end with cervical alae; ventral view. 10. Circumoral lips; apical view. Fig. 11. - Ancylostoma ceylanicum. Mouth cavity with two pairs of cuticular teeth; subapical view. Fig. 12. - Ancylostoma tubaeforme. Mouth cavity with three pais of cuticular teeth; subapical view. Figs 13-14. - Oncicola sp. Proboscis; subapical views (SEM photomicrographs). 
1968, 1973; Areekul et al., 1970; Chowdhury \& Schad, 1972). The high prevalence of $A$. ceylanicum in cats from Laos may indicate its common occurrence in this country, in both the feline and the human population. Giboda et al. (1991c) reported the prevalence of infection of Laotians with hookworms up to $48 \%$ ( $\mathrm{n}=$ 112 ) in the Keo-Oudom District near the Nam Ngum water reservoir; due to the morphological similarity of hookworm eggs, the possibility that some samples actually contained eggs of $A$. ceylanicum cannot be excluded.

The dog tapeworm Dipylidium caninum can accidentally infect man, especially in countries where it is known to occur in cats, with most cases reported from children (Hasslinger, 1987; Chappel et al., 1990; Muller, 2002). The cestode Taenia taeniaeformis occurs frequently in the small intestine of cats and, much more rarely, of dogs and other carnivores. Its findings in humans are exceptional and without medical importance (Kassai, 1999; Hoberg, 2002).

Spirurid nematodes found in the stomachs of domestic and Bengal cats from Laos, reported as Spirurata sp. by Giboda et al. (1991b), were identified as Physaloptera praeputialis, a common parasite in the stomach of felids and reported from cats in the USA and Asia (Segal et al., 1968; Rajavelu \& Raja, 1988; Roberts \& Janovy, 1996).

Human infections with species of Physaloptera have not been reported, except for accidental cases caused by P. caucasica (Linstow, 1902), a parasite of monkeys in tropical regions and other countries (Tongson \& Eduardo, 1982; Roberts \& Janovy, 1996).

The only acanthocephalan found in cats from Laos belongs to the genus Oncicola Travassos, 1916 (see Schmidt, 1972). Medical importance of species of this group of acanthocephalans is negligible (Roberts \& Janovy, 1996; Muller, 2002).

The importance of cats as a source of human parasites was first mentioned by Chandler (1925). Other authors (Hasslinger et al., 1974; Hinz, 1980; Hasslinger, 1987) pointed out that man and cats share some species of parasites, in particular helminths. The present study has demonstrated that the examination of cats may provide valuable information about the occurrence, species composition and biology of potential human parasites, as it was in studies on human parasitoses in Laos in 1989 (Ditrich et al., 1990; Giboda et al., 1991a-c).

\section{ACKNOWLEDGEMENTS}

T The authors are indebted to their Laotian co-workers, especially to Mr. Boon Thue and Mr. Buali, for technical help, to Dr. M. Giboda, head of the Czechoslovak parasitological team working in Laos in 1989 on fish-borne and other parasitic diseases, and
Dr. J. Gutvirth for help in host sampling, to Dr. F. Moravec, Institute of Parasitology, AS CR, Ceské Budějovice, for valuable advice regarding the identification of nematodes, and to the staff of the Laboratory of Electron Microscopy for help in preparation of specimens for SEM observations. Flora Logan (University of Glasgow; Work Placement Program) kindly checked the English of a draft of the manuscript.

\section{REFERENCES}

ABD El-Kader SAAD A.I. \& ABED G.H. Studies on the life cycle of Haplorchis pumilio (Looss, 1896) Looss, 1899 with morphological redescription of larval and adult stages. Journal of Egyptian Society of Parasitology, 1995, 25, 795-806.

AndERSON R.C. Nematode parasites of vertebrates: their development and transmission. Second edition. CABI Publishing, Wallingford, UK, 2000, 650 p.

Areekul S., Radomyos P. \& Viravan C. Preliminary report on Ancylostoma ceylanicum infection in Thai people. Journal of the Medical Association of Thailand, 1970, 53, 315-320.

asato R., Hasegawa H., Kuniyoshi S. \& Higa T. Prevalence of helminthic infections in cats in Okinawa Island, Japan. Japanese Journal of Parasitology, 1986, 35, 209-214.

Ausayakhun S., Siriprasert V., Morakote N. \& Taweesap K. Ocular sparganosis in Thailand. Southeast Asian Journal of Tropical Medicine and Public Health, 1993, 24, 603-606.

ChaI J.Y. \& LeE S.H. Intestinal trematodes of humans in Korea: Metagonimus, heterophyids and echinostomes. Korean Journal of Parasitology, 1990, 28, 103-122.

Chandler A.C. The helminthic parasites of cats in Calcutta. Indian Journal of Medical Research, 1925, 13, 213-227.

Chang J.H.M., Lin O.S. \& YeH K.T. Subcutaneous sparganosis - a case report and a review of human sparganosis in Taiwan. Kaobsiung Journal of Medical Sciences, 1999, 15, 567-571. (Cited after Helminthological Abstracts 2000, Vol. 69, No. 3, p. 108)

Chappel C.L., Enos J.P. \& Penn H.M. Dipylidium caninum, an underrecognized infection in infants and children. Pediatric Infectious Disease Journal, 1990, 9, 745-747.

ChOWdHuRy A.B. \& Schad G.A. Ancylostoma ceylanicum: a parasite of man in Calcutta and environs. American Journal of Tropical Medicine and Hygiene, 1972, 21, 300301.

Daengsvang S. Gnathostomiasis. In: CRC Handbook Series in Zoonoses, Section C, Volume II, ed. M.G. Schultz, CRC Press, Inc., Boca Raton, Florida, 1982, 147-180.

Davies H.D., Sakuls P. \& Keystone J.S. Creeping eruption. A review of clinical presentation and management of 60 cases presenting to a tropical disease unit. Archives of Dermatology, 1993, 129, 588-591.

Ditrich O., Giboda M., Scholz T. \& Beer S.A. Comparative morphology of eggs of the Haplorchiinae (Trematoda: Heterophyidae) and some other medically important heterophyid and opisthorchiid flukes. Folia Parasitologica, 1992, 39, 123-132. 
Ditrich O., Scholz T. \& Giboda M. Occurrence of some medically important flukes (Trematoda: Opisthorchiidae and Heterophyidae) in Nam Ngum water reservoir, Laos. Southeast Asian Journal of Tropical Medicine and Public Health, 1990, 21, 482-488.

Fujinami F., Tanaka H.\& Ohshima S. Prevalence of protozoan and helminth parasites in cats for experimental use obtained from Kanto Area, Japan. Experimental Animals, 1983, 32, 133-137.

Fukase T., Chine S. \& Itagaki H. Helminth parasites of stray domestic cats in Kanagawa Prefecture, Japan. Journal of Japanese Veterinary Medicine Association, 1984, 37, 15-19.

Giboda M., Ditrich O., Scholz T., Tuathong V. \& Sayseng B. Country report: current status of food-borne parasitic zoonoses in Laos. Southeast Asian Journal of Tropical Medicine and Public Health, 1991a, 22 (Suppl.), 56-61.

Giboda M., Ditrich O., Scholz T., Viengsay T. \& BouaPHANH S. Human Opisthorchis and Haplorchis infections in Laos. Transactions of the Royal Society of Tropical Medicine and Hygiene, 1991b, 85, 538-540.

Giboda M., Viengsay M., Bouaphanh S. \& Ditrich O. Intestinal parasites, their epidemiology and antiamoebic antibodies in Laos. Bulletin de la Societé de Pathologie Exotique, 1991c, 84, 184-193.

Glickman L.T. The epidemiology of human toxocariasis. In: Toxocara and Toxocariasis: clinical, epidemiological and molecular perspectives, ed. Lewis J.W. and Maizels R.M., Birbeck \& Sons Limited, Birmingham, UK, 1993, 3-10.

Harinasuta C. \& VAJRAsthira S. Opisthorchiasis in Thailand. Annals of Tropical Medicine and Parasitology, 1960, 54, 100-105.

Hasslinger M.A. The importance of parasites in cats in Egypt. Journal of the Egyptian Veterinary Medicine Association, 1987, 47, 743-750.

Hasslinger M.A., Jonas D. \& Berger W. Zur Stellung der Hauskatze in der Epidemiologie menschlicher Wurminfektionen unter besonderer Berücksichtigung von Toxocara mystax. Tierärztliche Umschreiben, 1974, 29, 26-33.

Hinz E. Der Darmhelminthenbefall bei Strassenhunden in Bangkok, Thailand, und seine Bedeutung für die Gesundheit des Menschen. Zentralblatt für Bakteriologie und Hygiene, I Abt. Orig. B, 1980, 171, 79-85.

Hoberg E.P. Taenia tapeworms: their biology, evolution and socioeconomic significance. Microbes and Infection, 2002, 4, 859-866.

KASSAI T. Veterinary helminthology. Butterworth-Heinemann, Oxford, GB, 1999, 260 p.

KHAN A.H. Prevalence of helminth parasites in cats in Lucknow District of Uttar Pradesh (India). Helminthologia, 1987, 24, 275-279.

Magnaval J.F., Glickman L.T., Dorchies P. \& Morassin B. Highlights of human toxocariasis. Korean Journal of Parasitology, 2001, 39, 1-11.

MIYAZAKI I. On the genus Gnathostoma and human gnathostomiasis with special reference to Japan. Experimental Parasitology, 1960, 9, 338-370.

Muller R. Worms and human disease. CABI Publishing, Wallingford, UK, 2002, 300 p.
Pearson J.C. A revision of the subfamily Haplorchinae Looss, 1899 (Trematoda: Heterophyidae). I. The Haplorchis group. Parasitology, 1964, 54, 601-676.

Radomyos P., Bunnag D. \& Harinasuta T. Haplorchis pumilio (Looss) infection in man in Northeastern Thailand. Southeast Asian Journal of Tropical Medicine and Public Health, 1983, 14, 223-227.

Radomyos P., Charoenlarp P., Radomyos B. \& TungtrongCHITR A. Two human cases of Stellantchasmus falcatus (Trematoda, Heterophyidae) infection in northeastern Thailand. Japanese Journal of Parasitology, 1990, 39, 7-11.

RajaVElu G. \& Raja E.E. On helminth parasites in domestic cat in Madras. Cheiron, 1988, 17, 11-14.

Rim H.J., Farag H.F., Sommani S. \& Cross J.H. Food-borne trematodes: Ignored or emerging. Parasitology Today, 1994, 10, 207-209.

Roberts L.S, Janovy J. (Jr.). Schmidt and Roberts' Foundations of Parasitology. Fifth edition. Wm C Brown Publishers, Dubuque, Indiana, 1996, $659 \mathrm{p}$.

Saito T., Yamaguchi H., Yoshida K., Kusaura J., Wada E., Morishige K. \& Tongu Y. Prevalence of parasites in domestic dogs and cats in Fukuyama City, Japan, in 1995. Journal of Veterinary Medicine, 1998, 51, 889-892.

Schmidt G.D. Revision of the class Acanthocephala Meyer, 1931, (phylum Acanthocephala), with emphasis on the Oligacanthorhynchidae Southwell et Macfie, 1925. Journal of Parasitology, 1972, 58, 290-297.

Scholz T. \& Ditrich O. Scanning electron microscopy of the cuticular armature of the nematode Gnathostoma spinigerum Owen, 1836 from cats in Laos. Journal of Helminthology, 1990, 64, 255-262.

Scholz T., Ditrich O. \& Giboda M. Larval stages of medically important flukes (Trematoda) from Vientiane province, Laos. Part I. Metacercariae. Annales de Parasitologie bumaine et comparée, 1991b, 65, 238-243.

Scholz T., Ditrich O. \& GibOda M. Study on the body surface morphology of the developmental stages of the liver fluke, Opisthorchis viverrini (Trematoda: Opisthorchiidae). Annales de Parasitologie humaine et comparée, 1992, 67, $82-90$.

Scholz T., Ditrich O., TÙma M. \& Giboda M. Study of the body surface of Haplorchis yokogawai (Katsuta, 1932) and H. taichui (Nishigori, 1924) (Trematoda: Heterophyidae). Southeast Asian Journal of Tropical Medicine and Public Health, 1991a, 22, 443-448.

Segal D.B., Humprey J.M., Edwards S.E. \& Kirby M.D. Parasites of man and domestic animals in Vietnam, Thailand, Laos, and Cambodia. Experimental Parasitology, 1968, 23, 142-158.

Shaikh H., HuQ M. M., Karim M.J. \& Munzur M.K.M. Incidence of helminth parasites of domestic and wild cats and of jackals in Bangladesh. Indian Journal of Parasitology, 1982, 6, 245-247.

Sohn W.M., Chai J.Y. \& LeE S.H. A human case of Stellantchasmus falcatus infection. Korean Journal of Parasitology, 1989, 27, 277-279.

TAYLOR M.R.H. The epidemiology of ocular toxocariasis. Journal of Helminthology, 2001, 75, 109-118. 
TOngson M.S. \& Eduardo S.L. Physalopteriasis. In: CRC Handbook series in zoonoses. Section C. Volume II, ed. Schultz M.G., CRC Press, Inc., Boca Raton, Florida, 1982, 255-256.

VeEna TANDON \& ImKongwapang R. Natural infection of sparganum in frogs in Nagaland (northeastern India) - an Amphibia-borne zoonosis? Zoo's Print Journal, 1999, 14, 13-16.

Velasquez C.C. Heterophyidiasis. In: CRC Handbook series in zoonoses. Section C, Vol. III., ed. Hillyer G.V. and Hopla C.E., CRC Press, Boca Raton, Florida, 1982, 99-107.

Velasquez C.C. \& CaBrera B.C. Ancylostoma ceylanicum (Looss, 1911) in a Filipino woman. Journal of Parasitology, 1968, 54, 430-431.

Wykoff D.E., Harinasuta C., Juttujudata P. \& Winn M.M. Opisthorchis viverrini in Thailand - the life cycle and comparison with O.felineus. Journal of Parasitology, 1965, 51, 207-231.

Yoshida Y., Окамото K. \& ChiU J.K. Ancylostoma ceylanicum infection in dogs, cats, and man in Taiwan. American Journal of Tropical Medicine and Hygiene, 1968, 17, 378-381.

Yoshida Y., Okamoto K., Matsuo K., Kwo E.H. \& RetnasaBOPATHY A. The occurrence of Ancylostoma braziliense (de Faria, 1910) and Ancylostoma ceylanicum (Looss, 1911) in Malaysia. Soutbeast Asian Journal of Tropical Medicine and Public Health, 1973, 4, 498-503.

Reçu le 8 février 2003

Accepté le 23 mai 2003 